Abstracta Iranica Abstracta Iranica

Revue bibliographique pour le domaine irano-aryen

Volume 34-35-36 | 2017

Comptes rendus des publications de 2011-2013

\title{
Amy Landau. From Poet to Painter: Allegory and Metaphor in a Seventeeth-Centurt Persian Paintings by Muhammad Zaman, Master of Farangī-Sāzì
}

Isabelle Imbert

\section{(2) OpenEdition \\ Journals}

Édition électronique

URL : http://journals.openedition.org/abstractairanica/41238

DOI : 10.4000/abstractairanica.41238

ISSN : 1961-960X

Éditeur :

CNRS (UMR 7528 Mondes iraniens et indiens), Éditions de l'IFRI

Référence électronique

Isabelle Imbert, « Amy Landau. From Poet to Painter: Allegory and Metaphor in a Seventeeth-Centurt Persian Paintings by Muhammad Zaman, Master of Farangī-Sāzī », Abstracta Iranica [En ligne], Volume 34-35-36 | 2017, document 2, mis en ligne le 15 juillet 2016, consulté le 30 septembre 2020. URL : http://journals.openedition.org/abstractairanica/41238; DOI : https://doi.org/10.4000/

abstractairanica. 41238

Ce document a été généré automatiquement le 30 septembre 2020.

Tous droits réservés 
Amy Landau. From Poet to Painter: Allegory and Metaphor in a SeventeethCenturt Persian Paintings by Muhammad Zaman, Master of FarangīSāzī

Isabelle Imbert 


\section{RÉFÉRENCE}

Amy Landau. « From Poet to Painter: Allegory and Metaphor in a Seventeeth-Century Persian Paintings by Muhammad Zaman, Master of Farangī-Sāzī ». Muqarnas, vol. 28, 2011, p. 101-131.

L'A. revient sur la carrière d'un des peintres les plus célèbres de la période moderne : Mohammad Zamān. Cet article, issue de sa thèse consacrée à l'artiste et soutenue en 2006, se concentre sur les peintures ajoutées à la Hamse de Šāh Ṭahmāsp, produite entre 946/1539 et 949/1543. Trois scènes portent la signature de Mohammad Zamān : Bahram Gur tuant le dragon, Fitna étonnant Bahram Gur et une dernière faussement identifiée comme Bahram Gur et la princesse indienne. Par une analyse iconographique, Amy Landau replace la scène dans l'épisode de Turktazi et la reine des Fées. Les trois peintures de la Hamse constituent un sommet du Farangī Sāz. Développé durant le règne de Šāh Soleymān (r. 1666-1694), ce style incorpore des éléments issus de la copie de gravures européennes pour aboutir à un syncrétisme artistique dont Mohammad Zamān est un des représentants les plus fameux. Šāh Soleymān donne d'ailleurs ses traits à Turktazi dans la peinture de la Hamse, rattachant ainsi la restauration du manuscrit au patronage du souverain.

\section{AUTEURS}

\section{ISABELLE IMBERT}

Université Paris-Sorbonne 